Jurnal Kesehatan Perintis (Perintis's Health Journal) 7 (1) 2020: 16-21

Contents list available at JKP website

Jurnal Kesehatan Perintis (Perintis's Health Journal)

Journal homepage: https://jurnal.stikesperintis.ac.id/index.php/JKP

\title{
Dukungan Sosial Pada Ibu Postpartum Primipara Terhadap Kejadian Postpartum Blues
}

\author{
Riani Astri ${ }^{1}$, Ariani Fatmawati ${ }^{\star 2}$, Nina Gartika ${ }^{2}$ \\ ${ }^{1}$ Rumah Sakit Khusus Ibu dan Anak Bandung, Jawa Barat, Indonesia \\ ${ }^{2}$ STIKes Aisyiyah Bandung, Jawa Barat, Indonesia
}

Article Information :

Submission: Jun 3, 2020; Revised: Jun 30, 2020; Accepted:Jun 30, 2020; Available online: Jul 12, 2020

*Corresponding author : rianiners@gmail.com

\begin{abstract}
ABSTRAK
Postpartum Blues (PPB) jika tidak ditangani akan berkembang menjadi depresi atau psikosa postpartum. Masalah ini dialami oleh sebagian ibu postpartum karena peran barunya sebagai seorang ibu. Penelitian ini bertujuan mengidentifikasi hubungan dukungan sosial pada ibu postpartum primipara terhadap kejadian postpartum blues. Jenis penelitian adalah kuantitaif dengan pendekatan deskiptif korelasi, jumlah sampel 106 orang dengan kriteria inklusi ibu postpartum hari 1-7, semua jenis persalinan, ibu sadar penuh, primipara dan bersedia menjadi responden. Penentuan jumlah sampel dengan menggunakan consecutive sampling dengan tehnik pengumpulan data menggunakan kuesioner Edinburg Postnatal Depression Scale (EPDS) dan postpartum support system and family coping quessionaire. Analisa data dengan chi-square. Ibu postpartum primipara mendapatkan dukungan sosial baik sebanyak $89.6 \%$ dan sebanyak $40,6 \%$ ibu primipara mengalami postpartum blues. Hasil analisis bivariate didapatkan $p$-value 0,007 ( $p$ value $<0,005)$ yang berarti terdapat hubungan antara dukungan sosial terhadap kejadian postpartum blues pada ibu primipara di RSKIA Kota Bandung. Hasil penelitian ini menunjukkan bahwa penting untuk deteksi dini kejadian postpartum blues atau depresi postpartum pada saat ibu hamil.
\end{abstract}

Kata Kunci: dukungan sosial, primipara, postpartum blues

\section{ABSTRACT}

Postpartum Blues (PPB) if left untreated will develop depression or postpartum psychosis. This problem is experienced by some postpartum mothers because of her new role as a mother. This study aims to identify the relationship of social support in primiparous postpartum mothers to the incidence of postpartum blues. This type of research is quantitative with a descriptive correlation approach, a sample of 106 people with inclusion criteria postpartum mothers day 1-7, all types of labor, fully conscious mothers, primiparous and willing to be respondents. Determination of the number of samples using consecutive sampling with data collection techniques using the Edinburg Postnatal Depression Scale (EPDS) questionnaire and postpartum support system and family coping quessionnaire. Data analysis with chi-square. Primiparous postpartum mothers get good social support as much as $89.6 \%$ and $40.6 \%$ of primiparous mothers experience postpartum blues. Bivariate analysis results obtained $p$-value 0.007 ( $p$-value $<0.005)$ which means there is a relationship between social support for postpartum blues events in primiparous mothers in RSKIA 
Bandung. The results of this study indicate that it is important for early detection of postpartum blues events or postpartum depression when pregnant women.

Keywords : primipara,postpartum blues, social support

\section{PENDAHULUAN}

Masa nifas merupakan masa semua organ reproduksi perempuan setelah melahirkan ke kondisi semula seperti sebelum hamil (Lowdermilk et al., 2013). Proses pemulihan pada masa nifas disebut dengan adaptasi postpartum. Adaptasi postpartum terdiri dari dua yaitu adaptasi fisiologi dan psikologis.

Adaptasi psikologis pada ibu postpartum dimulai ketika seorang ibu mulai merawat dan mengurus bayinya. Hal ini merupakan peran dan tanggung jawab baru bagi setiap wanita setelah melahirkan (Sylvén et al., 2017). Peran dan tanggung jawab baru ini sering membuat ibu merasa tidak percaya diri dan mengalami stress. Ibu merasa sedih dan putus asa karena belum mampu untuk merawat bayi dengan baik. Kondisi ini membuat ibu menjadi lebih sensitif. Kondisi seperti ini dikenal dengan baby blues atau postpartum blues. Kondisi ini muncul pada minggu pertama sampai kedua setelah melahirkan yang puncaknya pada hari ke tiga sampai kelima. Kejadian postpartum blues ini dialami oleh duapertiga ibu postpartum. Di Asia kejadian postpartum blues mencapai $26-85 \%$ sedangkan di Indonesia berkisar 50-70\% (Restyana, 2014).

Penyebab postpartum blues belum diketahui secara pasti. Banyak factor yang dapat menyebabkan postpartum blues, salah satunya yaitu dukungan sosial (Ningrum, 2017). Dukungan sosial bisa berasal dari suami, keluarga dan tetangga/lingkungan. Penyebab postpartum blues yang lain yaitu terjadi pada wanita primipara karena berada dalam masa adaptasi, bagi wanita primipara kondisi setelah melahirkan dapat menimbulkan stres, karena perubahan peran (Masruroh, 2013), dukungan suami dan kesiapan ibu dalam melahirkan (Susanti \& Sulistiyanti, 2016), usia ibu, paritas dan dukungan sosial suami (D. A. Fatmawati, 2015), pekerjaan dan dukungan keluarga (Wahyuni et al., 2014).

Gejala yang dialami oleh ibu adalah perasaan sedih, sensitive, mudah menangis, insomnia, mudah cemas, merasa tidak berdaya dan tidak berguna, anoreksia. Kondisi ini berlangsung beberapa jam setelah persalinan sampai beberapa hari tergantung dari dukungan yang diterima oleh ibu. Jika tidak tertangani akan berkembang menjadi lebih berat pada beberapa minggu dan bulan kemudian (Murtiningsih, 2012).

Postpartum blues akan menyebabkan ibu yang mengalaminya merasa tidak nyaman, apabila gejala postpartum blues menetap dan tidak cepat tertangani akan berubah menjadi depresi atau psikosa postpartum dengan menampakkan gejala yang membahayakan seperti menyakiti diri sendiri dan bayinya, juga dapat berdampak pada proses laktasi. Saat kondisi ibu stress akan mengeluarkan hormone adrenalin dan kortisol yang akan menghambat pengeluaran hormone prolactin dan oksitosin sehingga akan berpengaruh terhadap produksi dan pengeluaran air susu ibu (ASI). Selain berpengaruh terhadap ASI, juga dapat berpengaruh pada hubungan ibu dengan suami (D. A. Fatmawati, 2015).

Ibu postpartum remaja yang mengalami postpartum blues dapat mengalami gangguan psikososial. Gangguan psikososial ini dapat mengakibatkan gangguan ikatan tali kasih ibu dan anak dan cenderung tidak memberikan ASI (A. Fatmawati et al., 2018).

Beberapa hasil penelitian menunjukkan bahwa dukungan sosial dari keluarga, riwayat depresi sebelumnya dan kesulitan sosial ekonomi berpengaruh terhadap kejadian postpartum blues bahkan berujung pada depresi postpartum pada ibu usia remaja (Hymas \& Gyrard, 2019). Dukungan sosial dari keluarga, teman dan bidan/tenaga kesehatan berpengaruh terhadap kejadian depresi postpartum pada ibu usia (Nurfatimah \& Entoh, 2018). Dukungan sosial dan perencanaan kehamilan menunjukkan adanya hubungan dengan kejadian postpartum blues pada ibu remaja (A. Fatmawati \& Gartika, 2019).

Penelitian yang dilakukan memiliki perbedaan dengan penelitian sebelumnya yaitu pada respondennya. Penelitian sebelumnya dilakukan pada ibu remaja sementara pada penelitian ini dilakukan pada ibu primipara semua usia baik remaja maupun dewasa. Selain itu penelitian sebelumnya dilakukan pada ibu postpartum spontan tanpa 
komplikasi, sementara pada penelitian ini semua jenis persalinan dijadikan responden. Waktu pengambilan sampel pada penelitian ini adalah ibu postpartum hari 1-7, sementara pada penelitian sebelumnya sampai 3 bulan postpartum. Penelitian sebelumnya untuk mengetahui sampai kejadian depresi postpartum sementara pada penelitian ini hanya postpartum blues. Deteksi ini digunakan supaya perawat atau tenaga kesehatan lain dapat memberikan intervensi sehingga tidak menjadi depresi postpartum.

Di Indonesia ibu postpartum sebagian besar tidak menyadari mengalami postpartum blues dan di dalam masyarakat ada anggapan gejala-gejala yang muncul pada ibu baru adalah sesuatu hal yang wajar, terkait dengan angka kejadian postpartum blues, di Indonesia sendiri belum ada survey yang resmi dari pemerintah (Arfian, 2012). Salah satunya di RSKIA Kota Bandung, tidak terdapat pengkajian khusus untuk postpartum blues. Dari hasil uji kuesioner dengan menggunakan EPDS kepada 7 ibu post partum primipara, didapatkan hasil 5 orang dengan skor $\geq 12$ mengalami postpartum blues, sedangkan 2 orang dengan skor < 12 tidak postpartum blues. Tujuan dari penelitian ini untuk mengidentifikasi hubungan dukungan sosial terhadap postpartum blues pada ibu postpartum primipara.

\section{METODE PENELITIAN}

Jenis penelitian adalah kuantitatif dengan metode deskriptif korelasi. Desain penelitian cross sectional. Penelitian dilakukan di RSKIA Kota Bandung pada bulan November 2018Januari 2019. Jumlah populasi ibu postpartum primipara sebanyak 267 . Sampel yang diambil menggunakan teknik consecutive sampling yang memenuhi kriteria inklusi sebanyak 106 ibu postpartum primipara. Kriteria inklusi pada pemilihan sampel yaitu ibu postpartum hari 17, semua jenis persalinan, ibu sadar penuh, mampu membaca dan menulis.

Pengumpulan data dengan instrumen Edinbrugh Postnatal Depression Scale (EPDS) dan kuesioner postpartum support system and family coping quessionaire. Kuesioner EPDS terdiri dari 10 pernyataan dengan skor $\geq 12$ terjadi posrpartum blues dan $<12$ tidak terjadi postpartum blues. Kuesioner dukungan suami total skor 75, jika skor > 29 dukungan sosial baik dan $\leq 29$ dukungan sosial kurang. Pengumpulan data dilakukan di poli obstetric pada pagi dan sore hari. Ibu postpartum yang sesuai dengan kriteria inklusi akan dijadikan sampel. Pengambilan data dibantu oleh satu orang asisten pengambil data. Analisis data menggunakan analisis chi-square. Adapun kriteria pengujiannya adalah bila $p$ value < 0,05 maka secara statistik ada hubungan yang bermakna tetapi bila $p$ value $>0,05$, maka secara statistik tidak signifikan atau tidak ada hubungan yang bermakna.

\section{HASIL DAN PEMBAHASAN}

Distribusi Frekuensi Berdasarkan Usia, Jenis Persalinan, Tingkat Pendidikan, Pekerjaan Ibu, Pekerjaan Suami dapat dilihat pada tabel 1, didapatkan sebagian besar ibu postpartum berusia 20-35 tahun (87,7\%), dengan jenis persalinan lebih dari setengahnya dengan SC $(55,7 \%)$, lebih daru setengah responden berpendidikan SMA $(59,5 \%)$ dan pekerjaan suami paling banyak adalah swasta (67\%). Berdasarkan tabel 2 menunjukkan bahwa dukungan sosial pada ibu postpartum di RSKIA Kota Bandung sebagian besar mendapatkan dukungan baik $(89,6 \%)$ dan kejadian postpartum blues kurang dari setengahnya $(40,6 \%)$.

Berdasarkan tabel 3 menunjukkan bahwa sebagian besar ibu mendapatkan dukungan baik tidak mengalami postpartum blues sebanyak $64,2 \%$ dan mengalami postpartum blues sebanyak $35,8 \%$. Sementara ibu yang mendapatkan dukungan sosial yang kurang sebagian besar mengalami postpartum blues sebanyak $81,8 \%$ dan tidak mengalami postpartum blues sebanyak 18,2\%. Hasil analisis statistik chi-square didapatkan nilai $p$ value sebesar $0,007(p<0,05)$ berarti terdapat hubungan antara dukungan sosial terhadap kejadian postpartum blues pada ibu primipara di RSKIA kota Bandung.

Hasil penelitian lain menyatakan bahwa dukungan sosial merupakan salah satu faktor yang berhubungan dengan kejadian postpartum blues pada ibu remaja (A. Fatmawati \& Gartika, 2019), dukungan suami factor yang paling berhubungan dengan kejadian postpartum blues (Kurniasari \& Astuti, 2015) dan dukungan sosial bidan/tenaga kesehatan factor yang paling dominan memengaruhi kejadian postpartum blues pada ibu postpartum remaja (Nurfatimah \& Entoh, 2018).

lbu primipara lebih stres ketika menghadapi kelahiran anak pertama, karena 
wanita primipara mempunyai pengalaman lebih sedikit daripada ibu multipara. Ibu primipara memerlukan waktu yang lebih lama untuk beradaptasi dengan peran dan tanggung jawab barunya (Kusuma, 2017).

Tabel 1 Distribusi Frekuensi Berdasarkan Usia, Jenis Persalinan, Tingkat Pendidikan, Pekerjaan Ibu, Pekerjaan Suami

\begin{tabular}{lcc}
\hline \multicolumn{1}{c}{ Karakteristik } & $\mathbf{f}$ & $\%$ \\
\hline Usia & & \\
$<20$ tahun & 10 & 9,4 \\
20-35 tahun & 93 & 87,7 \\
>35 tahun & 3 & 2,8 \\
Total & 106 & 100,0 \\
Jenis Persalinan & & \\
Spontan & 45 & 42,4 \\
Sectio cesarean & 59 & 55,7 \\
Vacum/forcep & 2 & 1,9 \\
Total & 106 & 100,0 \\
Pendidikan & & \\
SD & 4 & 3,8 \\
SMP & 20 & 18,9 \\
SMA & 63 & 59,4 \\
PT & 19 & 17,9 \\
Total & 106 & 100,0 \\
Pekerjaan Suami & & \\
Buruh & 16 & 15,1 \\
Wiraswasta & 19 & 17,9 \\
Swasta & 71 & 67 \\
Total & 106 & 100,0 \\
\hline
\end{tabular}

Tabel 2. Distribusi Frekuensi Dukungan Sosial dan Kejadian Postpartum Blues

\begin{tabular}{lcc}
\hline \multicolumn{1}{c}{ Variabel } & f & $\%$ \\
\hline Dukungan Sosial & 95 & 89,6 \\
$\begin{array}{l}\text { Baik } \\
\text { Kurang } \\
\text { Kejadian }\end{array}$ & 11 & 10,4 \\
$\begin{array}{l}\text { Postpartum Blues } \\
\text { Tidak Postpatum }\end{array}$ & 63 & 59,4 \\
$\begin{array}{l}\text { Blues } \\
\text { Postpartum Blues }\end{array}$ & 43 & 40,6 \\
\hline
\end{tabular}

Ibu primipara memerlukan dukungan yang kuat dari lingkungan seperti suami, orang tua/keluarga, teman dna tenaga kesehatan. Peran bidan/tenaga kesehatan sangat dibutuhkan oleh ibu postpartum primipara dalam membimbing dan membina penyesuaian diri terhadap peran barunya (Wartisa, 2015).

Masa adaptasi psikologis postpartum dapat terlewati dengan dukungan sosial dalam menghadapi masalah yang di hadapinya. Sumber dukungan sosial dapat berasal dari suami, orang tua, sahabat, teman, tetangga dan petugas kesehatan. Peran suami dalam meminimalkan postpartum blues diantaranya memberikan dukungan (Irawati \& Yuliani, 2014).

Tabel 3. Hubungan Dukungan Sosial dengan Kejadian Postpartum Blues pada lbu Postpartum Primipara

\begin{tabular}{|c|c|c|c|c|c|c|c|}
\hline \multirow{3}{*}{ Dukungan Sosial } & \multicolumn{4}{|c|}{ Kejadian Postpartum Blues } & \multirow{2}{*}{\multicolumn{2}{|c|}{ Total }} & \multirow{3}{*}{$P$ Value } \\
\hline & \multicolumn{2}{|c|}{$\begin{array}{c}\text { Tidak Postpartum } \\
\text { Blues }\end{array}$} & \multicolumn{2}{|c|}{$\begin{array}{c}\text { Postpartum } \\
\text { Blues }\end{array}$} & & & \\
\hline & f & $\%$ & f & $\%$ & $\mathbf{f}$ & $\%$ & \\
\hline Kurang & 2 & 18,2 & 9 & 81,8 & 11 & 10,4 & \\
\hline Baik & 61 & 64,2 & 34 & 35,8 & 95 & 89,6 & 0,007 \\
\hline Total & 63 & 59,4 & 43 & 40,6 & 106 & 100,0 & \\
\hline
\end{tabular}

Bentuk dukungan social yang diharapkan oleh ibu postpartum primipara dapat berasal dari suami, keluarga, teman, tetangga dan tenaga kesehatan karena kondisi fisik dan psikologis menjadi lemah (Nurfatimah \& Entoh, 2018). Kesejahteraan kondisi psikologis ibu akan meningkat dengan adanya dukungan social yang baik (Easterbrooks et al., 2016). lbu postpartum yang kurang mendapatkan dukungan dari suami dan keluarga akan menyebabkan ibu postpartum mengalami postpartum blues (Anuradha \& Sebanti, 2011).
Dukungan yang diberikan oleh keluarga dapat memberikan rasa nyaman dan tenang, sehingga dapat menjadi sumber kekuatan bagi ibu postpartum (Reid \& Taylor, 2015).

Dukungan sosial dapat berupa dukungan emosional, dukungan instrumental, dan dukungan penghargaan. Bentuk dukungan sosial yang diberikan secara emosional yang diberikan pada ibu yaitu menunjukkan rasa peduli dan perhatian dengan mendampingi ibu pada saat melahirkan dan menghibur pada saat ibu sedih/ menangis sehingga harga diri 
ibu meningkat dan ibu merasa nyaman, bentuk dukungan instrumental membantu ibu dalam merawat dan mengasuh bayi, membantu mengerjakan pekerjaan rumah tangga atau memenuhi kebutuhan ibu, bentuk dukungan penghargaan yaitu memberikan pujian atau menghargai usaha ibu dalam merawat bayi dan mengurus pekerjaan rumah tangga, sehingga ibu menjadi bertambah semangat dalam menjalankan peran barunya sebagai ibu dan ibu merasa dirinya berarti / bernilai (Yuliawan et al., 2014).

Setelah melahirkan ibu memerlukan informasi mengenai cara perawatan bayi di rumah, cara perawatan diri setelah melahirkan dan informasi yang lainnya terutama ibu primipara sehingga ibu dapat beradaptsi dengan perubahan fisik dan psikologi yang terjadi sehingga ibu memerlukan dukungan informasional, dukungan tersebut bisa diperoleh dari keluarga, petugas kesehatan, teman atau tetangga. Pada masa transisi, dukungan sosial mencegah terjadinya postpartum blues (Leahy-Warren et al., 2011).

Bentuk dukungan sosial yang yang dapat diberikan pada ibu postpartum primipara menyediakan informasi, layanan perawatan dengan menyediakan pelayanan, perawatan, sesuai yang dibutuhkan untuk menghadapi stress dan tekanan. Diharapkan dengan adanya dukungan yang baik tidak terjadi postpartum blues (Wahyuni et al., 2014).

Dukungan sosial dapat mencegah kejadian postpartum blues. Jika dukungan sosial yang didapatkan oleh ibu postpartum primipara kurang dan tidak segera ditangani akan meningkatkan kejadian postpartum blues (Hymas \& Gyrard, 2019).

\section{KESIMPULAN}

Studi ini menunjukkan bahwa terdapat hubungan yang signifikan antara dukungan social pada ibu postpartum primipar dengan kejadian postpartum blues di RSKIA Kota Bandung. Sebagian besar ibu postpartum primipara mendapatkan dukungan sosial yang baik dan yang mengalami postpartum blues kurang dari setengahnya.

\section{UCAPAN TERIMA KASIH}

Ucapan terima kasih peneliti persembahkan kepada semua pihak yang membantu dalam penelitian ini. Adapun pihak tersebut adalah Direktur RSKIA Kota Bandung, Bidang Keperawatan dan Diklat RSKIA Kota
Bandung, dan Kepala Ruangan Ruang Nifas dan Poliklinik RSKIA Kota Bandung.

\section{REFERENSI}

Anuradha, G., \& Sebanti, G. (2011). Evaluation of Postpartum Depression in a Tertiary Hospital. The Journal of Obstetrics and Gynecology of India, 61(5), 528-530. https://doi.org/10.1007/s13224-011-00779

Arfian, S. (2012). Baby Blues: mengenali penyebab, mengetahui gejala dan mengantisipasinya. Metagraf.

Easterbrooks, M. A., Kotake, C., Raskin, M., \& Bumgarner, E. (2016). Patterns of Depression Among Adolescent Mothers: Resilience Related to Father Support and Home Visiting Program. American Journal of Orthopsychiatry, 86(1), 61-68. https://doi.org/10.1037/ort0000093

Fatmawati, A., \& Gartika, N. (2019). Hubungan Dukungan Psikososial dan Perencanaan Kehamilan dengan Kejadian Postpartum Blues pada Ibu Remaja. Jurnal BIMTAS, 3(2), 44-51.

Fatmawati, A., Rachmawati, I. N., \& Budiati, T. (2018). The influence of adolescent postpartum women's psychosocial condition on mother infant bonding. Enfermeria Clinica, 28, 203-206.

Fatmawati, D. A. (2015). Faktor Risiko Yang Berpengaruh Terhadap kejadian Post Partum Blues. Jurnal Eduhealth, 5(2).

Hymas, R., \& Gyrard, L. (2019). Predicting Postpartum Depression among adolescent mothers: A systematic review of risk. Journal of Affective Disorders, 246, 873-885.

Irawati, D., \& Yuliani, F. (2014). Pengaruh Faktor Psikososial dan Cara Persalinan Terhadap Terjadinya Postpartum Blues Pada Ibu Nifas. Hospital Majapahit, 6(1), $1-14$.

Kurniasari, D., \& Astuti, Y. A. (2015). Hubungan Antara Karakteristik lbu, Kondisi Bayi, dan Dukungan Sosial Suami dengan Postpartum Blues pada lbu dengan Persalinan SC di Rumah Sakit Umum Ahmad Yani Metro Tahun 2014. Jurnal Kesehatan Holistik, 9(3), 115-125.

Kusuma, P. D. (2017). Karakteristik Penyebab Terjadinya Depresi Postpartum Pada Primipara dan Multipara. Jurnal Keperawatan Notokusuma, 1(1), 15-19.

Leahy-Warren, P., McCarthy, G., \& Corcoran, 
P. (2011). Postnatal depression in first time mothers: prevalence and relationships between functional and structural social support at 6 and 12 weeks postpartum. Archives of Psychiatric Nursing, 25(3), 174-184.

Lowdermilk, Perry, S. E., \& Cashion, K. (2013). Keperawatan Maternitas Edisi 8 Buku 2. Elsevier.

Masruroh. (2013). Hubungan Antara Paritas Ibu dengan Kejadian Postpartum Blues. Jurnal Eduhealth, 3(2), 120-125.

Murtiningsih, A. (2012). Mengenal baby Blues dan Pencegahannya. Niaga Swadaya.

Ningrum, S. P. (2017). Faktor- Faktor Psikologis Yang Mempengaruhi Post Partum Blues. Jurnal IImiah Psikologi, 4(2), 205-218.

Nurfatimah, \& Entoh, C. (2018). Hubungan faktor demografi dan dukungan sosial dengan depresi pasca salin. Jurnal Profesi Medika, 11(2), 89-99. https://doi.org/10.1017/CBO97811074153 24.004

Reid, K., \& Taylor, M. (2015). Social Support, Stress, and Maternal Postpartum Depression: A Comparison of Supportive Relationships. Social Science Research, 54, 246-262.

Restyana, C. E. (2014). Kejadian Baby Blues Pada lbu Primipara di RSUD Bangil Pasuruan. Hospital Majapahit, 6(2), 29-
39.

Susanti, L. W., \& Sulistiyanti, A. (2016). Faktor Terjadinya Baby Blues Sindrom Pada Ibu Nifas. Jurnal Kebidanan DanF IImu Kesehatan, 3(2), 35-44.

Sylvén, S. M., Thomopoulos, T. P., Kollia, N., Jonsson, M., \& Skalkidou, A. (2017). Correlates of postpartum depression in first time mothers without previous psychiatric contact. European Psychiatry, 40 , 4-12. https://doi.org/10.1016/j.eurpsy.2016.07.0 03

Wahyuni, S., Murwati, \& Supiati. (2014). Faktor-Faktor Internal dan Eksternal Yang Mempengaruhi Depresi Post Partum. Jurnal Terpadu IImu Kesehatan, 3(2), 131-137.

Wartisa, F. (2015). Gambaran Tingkat Pengetahuan dan Sikap Bidan Pelaksana Pelayanan KIA dalam Mengkaji Permasalahan Kesehatan Jiwa lbu Nlfas di Wilayah Kerja Puskesmasn Mungka. Perintis Health Journal, 2(2), 149-153.

Yuliawan, D., Rahayuningsih, F. B., \& Ambarwati. (2014). Pengaruh Dukungan Suami Terhadap Kesejahteraan Ibu Nifas Di Wilayah Kerja Puskemas Kecamatan Miri kabupaten Sragen. Skripsi. Jurusan Keperawatan, Fakultas IImu Kesehatan [Universitas Muhammadiyah Surakarta]. http://eprints.ums.ac.id/30902/ 